advantages which it is likely to possess. The geographical position of the observatory peak is in longitude $121^{\circ} 36^{\prime} 40^{\prime \prime} \mathrm{W}$., latitude $37^{\circ} 2 \mathrm{r}^{\prime} 3^{\prime \prime} \mathrm{N}$.

\section{THE UNITED STATES WEATHER MAPS FOR OCTOBER AND NOVEMBER I878}

THE Wenther MaP for OCTOBER I878, which 1 appeared in our issue of August 19, showed an area of barometric depression overspreading the whole of the United States except a narrow patch extending from Great Salt Lake northwards. The depression was deepest in the region of Minnesota, where it was 0.150 inch under the average, stretching thence in a west-southwest direction toward San Diego, where it was $0^{\circ} \circ 77$ inch below the mean. On the Atlantic sea-board of the States, pressure was 0.014 inch in the south and 0.033 inch in the north below the average, and continued relatively low right across the Atlantic, the depression deepening to another minimum over the region including the north-west of Ireland and Scotland, where the greatest defect from the average reached 0.220 inch. This widespread depression stretched still further to eastward over the whole of Europe, except the extreme north of Scandinavia, the southern half of Italy, and all Russia, except its north-western provinces; and to southward at least as far as the equator. Another extensive region of low pressure covered the whole of Asia to the south of a line drawn from Shanghai round by Lake Balkash to the Persian Gulf, and extended south-eastward over the whole of the East India Islands and Australasia as far as the east coast of New Zealand, where atmospheric pressure rose to the average of the month. Pressure was also much under the average in Cape Colony and Mauritius.

On the other hand pressure was above the averagc over the head waters of the Platte and Missouri rivers, and from Vancouver Island northward over the northwest of America, rising to an excess of 0.180 inch in Alaska. But the most important area of high pressure covered Greenland, where it rose in the south to 0 '244 inch above the mean, and spread to the south-westward over Labrador, Newfoundland, and the Dominion of Canada as far as Montreal, and to the eastward over Iceland and the north of Scandinavia. A third area of extensive high pressure embraced the southern half of Italy, Greece, Egypt, Syria, nearly the whole of European Russia, and all Asia to the north of the area of low pressure already pointed out.

The distribution of the temperature anomalies of the month were of the simplest character in their relations to this anomalous distribution of the pressure. In the States to westward of the line of greatest barometric depression a reference to the map will show an extraordinary prevalence of strong north-west winds, where, consequently, temperatures were low, the defect from the average being $4^{\circ} .8$ at Winnipeg, $4^{\circ} \%$ on the Platte, $3^{\circ .6}$ on the Lower Columbia, and $2^{\circ} .6$ at San Diego. On the other hand, temperatures were everywhere above the average to the east of the Mississippi, the excess being nearly $5^{\circ} \circ$ in the New England States, but only about the third of a degree in Florida in the south, and in Newfoundland in the north.

Turning now to the great depression north-west of the British Islands, winds were northerly in Iceland and South Greenland, and there the temperature was respectively $2^{0 .} 3$ and $1^{\circ} \cdot 1$ below the average. Pressure rose higher from west to east over Europe as far as the Ural River, and into Asia as far as the Tohol, where it was fully o'Ico inch above the mean pressure of October. Westerly and southcrly winds accordingly ruled, and temperatures were everywhere above the average over this large tract of the earth's surface, the greatest excess being in the basin of the Dnieper, the maximum $7^{\circ} \cdot 6$ being recorded at Kiev. Pressure was $0^{\circ} 012$ inch in excess of the average in Syria and Egypt, but the northerly winds in Syria indicate a lower pressure southward, and in accordance therewith temperature was $2^{\circ} \circ$ at Beyrout and $0^{\circ .7}$ at Alexandria below the mean. From the rivers Ural and Tobol eastward through Siberia to the Sea of Okhotsk, temperatures were at all places below the average, the defect being from $2 \% 0$ to $3^{\circ} \circ$ in the basins of the Obi, Yenisei, Amoor, and Peiho.

It has been stated that pressure was $0^{\circ} 244$ inch above the average in South Greenland. At the two more northern stations however the excess was only 0.205 inch and $0^{\prime} 112$ inch; and in accordance with this diminution of the pressure northwards over Greenland it is to be noted that whilst in the extreme south of Greenland the temperature was below the average, it rose above it at the stations further north successively to $0^{\circ} \cdot 5,3^{\circ} \mathrm{I}$, and $4^{\circ} \mathrm{O}$.

NovemBer, I 878 , the U.S. Weather Map for which accompanies this notice, is memorable as the commencement of a period of unprecedentedly cold weather in the British Isles, which was protracted with scarcely even a temporary interruption to the middle of December, 1879.

In the United States pressure was above the mean to westward of the Mississippi and Missouri, the greatest excess, 0.090 inch, being near the sources of the latter river. Over the rest of the States and Canada pressure was under the average, there being at least three distinct centres of greater depression formed in this extensive region, one over Minnesota and Lake Winnipeg; a second along the St. Lawrence valley, and thence northward probably away towards the head of Baffin Bay, the greatest observed defect from the average being $0.13 \mathbf{I}$ inch near Anticosti; and a third along the north of the Gulf of Mexico. In Alaska pressure was fully half an inch below the mean of November.

But the most marked feature of the month was the development of a region of high pressure in mid-Atlantic and thence northward over Iceland and Greenland; the greatest excess, $0^{\circ} 362$ inch above the average, occurring in the north-west of Iceland. Immediately to eastward an area of low pressure overspread the whole of Europe, rising however to the average on the soutbern, eastern, and northern, as well as on the western, limits of the continent. Within this extensive depression, just as in the American depression, were developed several centres of still greater depression, viz., in the Baltic, North Sea, north-west of France, and Corsica. Another area of low pressure extended over India, the Philippine Islands, the East Indian Archipelago, Eastern Australia, Tasmania, and New Zealand. Over the whole of the rest of Asia, the north and east of Africa, and the south and west of Australia atmospheric pressure was above the average.

The temperature anomalies in the United States were quite extraordinary. Within and immediately to eastward of the western barometric depression temperatures were from $12^{\circ} .4$ to $13^{\circ} .7$ above the normal for the month, and over this region southerly winds prevailed; whereas immediately to westward, winds were westerly and northerly, and temperature fell to 3.4 above the normal, and on the Pacific coast to the normal. On the South Atlantic and Gulf States winds were northerly and the temperature only about half a degree above the normal. In connection with the St. Lawrence valley depression, the temperature anomalies were $6^{\circ} \circ$ in the Upper Lake region, $4^{\circ} \circ$ in Ohio valley, $3^{\circ} 6$ in the Lower Lake region, and $I^{\circ} \circ$ in the St. Lawrence valley above the normal.

In the west of Greenland, the pressure anomalies of the three stations proceeding northward were $0^{\prime} 130$ inch, 0.048 inch above, and 0.016 inch below the mean, and from the strong southerly winds resulting therefrom the temperature anomalies were respectively $6^{\circ} \cdot 8,9^{\circ} \mathrm{O}$, and $9^{\circ} .5$, almost rivalling the relative excesses of temperature which made the weather of this month so memorable over large portions of the States. As higher pressures 
ruled to westward from the North Cape to the Straits of Gibraltar, strong northerly winds swept over the whole of Western Europe, and the temperature everywhere fell below the average of the season, the defect being $4^{\circ} .3$ in the north of Norway, $4^{\circ} \circ$ in Farö, $4^{\circ} 4$ in Islay, $2^{\circ} .8$ in Jersey, and $5^{\circ} .6$ in Portugal. This area of low temperature stretched eastward into Europe as far as Vienna, Trieste, and Mentone.

To the east of the line of lowest pressure within the great barometric depression which covered all Europe except its extreme outskirts, temperatures were above the average, and greatly so as far east as the head waters of Yenisei, and thence round by Taschkend, Syria, and the north of Africa. Over the greater portion of this broad region the excess was not less than $5^{\circ} \circ$, and in the north of the Black Sea it reached as high as $9^{\circ} .4$ above the normal. In Eastern Siberia, Mantchooria, and Northern China very low temperatures prevailed, a deficiency of $8^{\circ} .1$ being recorded on the Upper Amoor.

The chief features of the meteorology of the northern hemisphere for November, 1878 , and they are very striking, were these :-(I) The almost unprecedently high temperature, amounting to from $6^{\circ} \circ$ to $13^{\circ} .7$ above the average over a large part of the United States, from $6^{\circ} .8$ to $9^{\circ} \cdot 5$ above the average over West Greenland; an excess of from $5^{\circ} \circ$ to $9^{\circ} 5$ over nearly the whole of European Russia and Western Siberia; (2) large and extensive barometric depressions formed in conjunction with these most anomalous temperatures; and (3) the formation of an area of high pressure-inclosed within remarkably steep gradients of mean monthly pressureover mid-Atlantic, extending thence in a north-easterly direction over Iceland toward Spitzbergen. To this it may be added that, whilst the high temperature anomaly of the surrounding low pressure regions rose to $13^{\circ} \%$ in the United States, $9^{\circ} 5$ in Greenland, and $9^{\circ} .4$ in Europe, the low temperature anomaly of the included region of high pressure fell only to $5^{\circ} \cdot 6$ below the normal at Coimbra, but over no great extent did it fall lower than $4^{\circ}$. o below the normal.

The U.S. Weather Maps for December, I878, and subsequent months, when low temperature anomalies were their out-standing features, will be looked forward to with the greatest interest as likely to throw light on the development of the meteorological conditions which impressed so arctic a character on our British weather during $1878-79$. In connection with this large problem it is impossible to overestimate the vital importance of a serious and searching inquiry into the causes which brought about the high temperature anomalies of the United States, Greenland, and Russia. It is to these anomalies in all likelihood we must look for an explanation of the origin of the high pressure in the included region of the North Atlantic, which was undoubtedly the immediate cause of the strong northerly winds and low temperatures which then prevailed over Western Europe.

\section{NOTES}

Prof. W. Chandler Roberts, F.R.S., will deliver the introductory lecture to his course of Metallurgy, on Monday next, October 4, at three o'clock, at the Science Schools, South Kensington Museum.

Mr. A. C. HAddon, Demonstrator of Comparative Anatomy in the University of Cambridge, with the sanction of the authorities, instead of conducting his class as usual during the Long Vacation at Cambridge, made the novel experiment last summer of taking it to the shores of Torbay, where he established a temporary zoological station on the principle of that at Naples, whither he himself had formerly been sent by the University to study. The attempt was very successful, and will doubtless be repeated another year. It was found that in addition to the ordinary class-fee of one guinea, a fee of four guineas covered the expenses of the extemporised laboratory, which was sufficiently provided with the instruments and appliances requisite in the present state of zoological study, as well as those of boat-hire for the dredging and surface-skimming excursions that formed the chief outdoor-work of the class, throughout the seven weeks of its stay; while embryological and histological dissections, together with the preparation and preservation of marine specimens for the University Museum, afforded constant occupation at home. The books, mostly monographs, needed for the determination and proper examination of the animals captured, were supplied by the superintendent of the museum, Mr. J. W. Clark, and the class received much valuable assistance from $\mathrm{Mr}$. A. R. Hunt, whose intimate knowledge of the fauna of Torbay was freely placed at its disposal.

Mr. MCGIBBon, the Superintendent of the Botanic Gardens, Cape Town, South Africa, a position which he has filled for thirty years, retires on a pension of $\mathrm{I}_{5} \mathrm{O} /$, a year. A movement is on foot to remove the Gardens from their present contracted site in Cape Town itself, and to create in the neighbourhood of the city a botanical establishment more worthy of the seat of South African Government. As a first step the appointment of Director has been offered to the well-known Cape botanist Prof. MacOwan, of Gill College, Somerset East. It is, however, doubtful whether the state of his health will allow of his undertaking it.

ON the 21st inst. there died at his residence in Camberwell, at the advanced age of 89 , Charles Johnson, who for more than forty-four years held the post of Professor of Botany at Guy's Hospital. He was editor of Sowerby's "English Botany," author of "Grasses of Great Britain," "British Poisonous Plants," "Ferns of Great Britain," and other valuable contribu. tions to natural history. In early life he took up the study of natural science, being one of the first members of the City Philosophical Society, of which Dr. Faraday and other eminent men were fellow-members. He was a high authority on agriculture and all subjects connected with economic botany.

THE death is announced of Prof. Samuel Stehman Haldeman, Professor of Comparative Philology in the Pennsylvania University, at the age of sixty-eight years. In 1836 he was employed in the geological survey of New Jersey, and in the following year in that of his native State, Pennsylvania. Dr. Haldeman filled the chair of Natural History in the University of Philadelphia and in a Delaware college, and was Professor of Geology and Chemistry to the State Agricultural Society of Pennsylvania prior to accepting the post which he held at his death. Other deaths announced are, on August 27, Dr. Hanstein, Professor of Botany and director of the Botanic Garden at Bonn; and on August 2I, Prof. E. B. Andrews, of the Geological Survey of Ohio, the author of several important contributions to the geology of that State.

Mr. DARWIn has forwarded to us an article contributed to an American medical journal by Dr. B. G. Wilder, Professor of Physiology in Cornell University, on "The Two Kinds of Vivisection-Sentisection and Callisection;" as he thinks the suggestion therein contained deserves consideration in this country. "All well-informed persons," Dr. Wilder writes, "are aware that the vast majority of vivisections, in this country at least, are performed under the influence of anrsthetics; but the enthusiastic zoölaters, who desire to abolish the objective method of teaching physiology, practically ignore this fact, and dwell chiefly upon the comparatively infrequent operations which are attended with pain. Having read the 